\title{
Peningkatan Hasil Belajar Tematik Tugasku Sehari-Hari Di Rumah Menggunakan Metode Kooperatif Make A Match Dengan Media Benda Konkret
}

\author{
Bety Andriyani \\ SDN Karangkandri 04 \\ betyfattah12345@gmail.com
}

\section{Article History}

accepted 01/11/2020 approved 08/11/2020 published 15/11/2020

\begin{abstract}
The purpose of this study was to improve student learning outcomes in thematic learning my daily assignments at home for Indonesian and math lesson content using the cooperative make a match method. This research is a classroom action research (PTK) which is conducted in three cycles, each cycle consisting of planning, implementation, and reflection stages. The subjects of this study were students of class II SDN Karangkandri 04 Cilacap in the 2020/2021 school year, totaling 29 students. Data collection techniques using tests. Data analysis includes data reduction, data presentation, and drawing conclusions. Research shows that the application of the make a match cooperative learning method can improve student learning outcomes in thematic learning my daily assignments at home for Indonesian and math lesson content in class II SDN Karangkandri 04 academic year 2020/2021 as evidenced by a percentage of 66\% (Indonesian) ; 59\% (mathematics) completeness of learning outcomes in cycle I, 93\% (Indonesian); 90\% (mathematics) in cycle II and 100\% (Indonesian \& mathematics) in cycle III. Keywords: learning outcomes, cooperative make a match method, students
\end{abstract}

\begin{abstract}
Abstrak
Tujuan penelitian ini adalah meningkatkan hasil belajar siswa pada pembelajaran tematik tugasku sehari-hari di rumah untuk muatan pelajaran bahasa indonesia dan matematika dengan metode kooperative make a match. Penelitian ini merupakan penelitian tindakan kelas (PTK) yang dilaksanakan dalam tiga siklus, setiap siklus terdiri dari tahap perencanaan, pelaksanaan, dan refleksi. Subjek penelitian ini adalah peserta didik kelas II SDN Karangkandri 04 Cilacap tahun pelajaran 2020/2021 yang berjumlah 29 peserta didik. Teknik pengumpulan data menggunakan tes. Analisis data meliputi reduksi data, penyajian data, dan penarikan kesimpulan. Penelitian menunjukkan bahwa penerapan metode pembelajaran Kooperative tipe make a match dapat meningkatkan hasil belajar siswa pada pembelajaran tematik tugasku sehari-hari di rumah untuk muatan pelajaran bahasa indonesia dan matematika di kelas II SDN Karangkandri 04 tahun pelajaran 2020/2021 yang dibuktikan dengan persentase $66 \%$ (bahasa indonesia) ; $59 \%$ (matematika) ketuntasan hasil belajar pada siklus I, 93 \% (bahasa indonesia); $90 \%$ (matematika) pada siklus II dan $100 \%$ (bahasa indonesia\&matematika) pada siklus III.

Kata kunci: hasil belajar, metode kooperative make a match, Siswa
\end{abstract}

Social, Humanities, and Education Studies (SHEs): Conference Series https://jurnal.uns.ac.id/shes

p-ISSN 2620-9284 e-ISSN 2620-9292 


\section{PENDAHLUAN}

Pencapaian tujuan pendidikan menjadi tantangan termasuk peningkatan mutu, relevansi dan efektivitas pendidikan sebagai tuntutan nasional sejalan dengan perkembangan dan kemajuan masyarakat, berimplikasi secara nyata dalam program pendidikan dan kurikulum sekolah.

Penelitian tindakan kelas yang dilakukan oleh peneliti mempunyai beberapa tujuan yang antara lain: meningkatkan hasil belajar tentang tematik subtema tugasku sehari-hari di rumah; mendeskripsikan peningkatan hasil belajar tematik subtema tugaskku sehari-hari di rumah siswa kelas II SD Negeri Karangkandri 04 setelah menggunakan pendekatan Bermain peran; menganalisis dampak penerapan pendekatan bermain peran terhadap peningkatan hasil belajar tematik subtema tugasku sehari-hari di rumah siswa kelas II SD Negeri Karangkandri 04.

Untuk mencapai tujuan tersebut, ternyata ditemui beberapa kendala, di antaranya: kurangnya motivasi siswa. Pada dasarnya siswa merasa malas dan kurang tertarik ketika mengikuti proses belajar mengajar di dalam kelas mungkin dikarenakan metode yang digunakan guru ketika menyampaikan materi pelajaran kurang tepat at au membosankan. Oleh karena itu , penulis merasa tertantang untuk meningkatkan hasil belajar siswa mengenai pembelajaran tematik subtema tugasku sehari-hari di rumah melalui model pembelajaran kooperatif tipe make a match dengan media benda konkret supaya siswa lebih tertarik mengikuti proses pembelajaran.

Metode Make a Match merupakan salah satu jenis dari metode dalam pembelajaran kooperatif. Metode ini dikembangkan oleh Lorna Curran. Kurniasih dan Sani (2015) menyatakan bahwa Make a Match adalah suatu model pembelajaran dimana siswa diajak mencari pasangan sambil belajar mengenai suatu konsep atau topik dalam suasana belajar yang menyenangkan. Sedangkan menurut Afandi (2013) Make a Match merupakan tipe model pembelajaran yang menggunakan kartu-kartu yang berisi pertanyaan-pertanyaan dan jawaban dari pertanyaan tersebut.Penerapan metode ini dimulai dengan teknik, yaitu siswa disuruh mencari pasangan kartu yang merupakan jawaban/soal sebelum batas waktunya, siswa yang dapat mencocokkan kartunya diberi poin. Penggunaan model pembelajaran kooperatif tipe Make a Match dalam proses pembelajaran tematik subtema Tugasku sehari-hari di Rumah itu guru dapat menciptakan suasana kelas yang lebih menyenangkan dan siswa menjadi aktif dalam pembelajaran. Sehingga siswa sebagai subjek tidak hanya mendengarkan penjelasan dari guru, tetapi juga dapat berperan aktif dalam pembelajaran dan bisa bekerja sama dengan baik dalam kelompoknya, sehingga subtema Tugasku sehari-hari di Rumah dapat tersampaikan dengan baik kepada siswa, begitu juga dengan siswanya dapat memahami subtema Tugasku sehari- hari di Rumah dengan baik. Dengan demikian dengan menggunakan model kooperatif tipe Make a Match diharapkan dapat meningkatkan hasil belajar pembelajaran Tematik Subtema Tugasku sehari-hari di Rumah.

Pada pembelajaran tematik tugasku sehari-hari dirumah di kelas II SDN Karangkandri 04 kesugihan Cilacap tahun Pelajaran 2020/2021. tujuan penelitian ini adalah meningkatkan hasil belajar siswa pada pembelajaran tematik Bahasa indonesia dan Matematika. 


\section{METODE}

Penelitian ini merupakan penelitian tindakan kelas (PTK) kolaboratif yang dilaksanakan dalam tiga siklus, setiap siklus terdiri dari tahap perencanaan, pelaksanaan, observasi, dan refleksi. Subjek penelitian ini adalah peserta didik kelas II SDN Karangkandri 04 kKesugihan Cilacap tahun pelajaran 2020/2021 yang berjumlah 29 peserta didik. Data yang dianalisis berupa data kualitatif yaitu penggunaan metode kooperative tipe make a match dan dan data kuantitatif yaitu hasil belajar tematik peserta didik. Teknik pengumpula data Analisis data meliputi reduksi data, penyajian data, dan penarikan kesimpulan.

\section{PEMBAHASAN}

Berdasarkan analisis hasil penelitian yang telah diuraikan maka pembahasan pada penelitian ini sebagai berikut.

\section{Penerapan Metode Make a match}

Hasil penelitian menunjukkan peningkatan penerapan metode kooperative tipe make a match yang diilakukan oleh guru, terlihat dalam tabel berikut.

Tabel 1. Peningkatan Penerapan Metode Kooperative tipe make a match

\begin{tabular}{lccc}
\hline \multicolumn{1}{c}{ Langkah } & $\begin{array}{c}\text { Siklus } \\
\text { I }\end{array}$ & $\begin{array}{c}\text { Siklus } \\
\text { II }\end{array}$ & $\begin{array}{c}\text { Siklus } \\
\text { III }\end{array}$ \\
\hline $\begin{array}{l}\text { Peserta didik dapat dengan mudah memahami kalimat } \\
\text { yang ditampilkan pada media power point }\end{array}$ & 2 & 3 & 4 \\
\hline $\begin{array}{l}\text { Peserta didik meampu memahami setiap materi yang } \\
\text { disampaikan menggunakan media benda konkret }\end{array}$ & 2 & 2 & 3 \\
\hline $\begin{array}{l}\text { Menjelaskan materi pelajaran secara ringkas pada semua } \\
\text { peserta didik }\end{array}$ & 3 & 3 & 3 \\
\hline $\begin{array}{l}\text { Memberi tugas kepada semua peserta didik untuk } \\
\text { mengerjakan LKPD yang telah disediakan oleh guru }\end{array}$ & 3 & 4 & 4 \\
\hline $\begin{array}{l}\text { Mengamati aktivitas belajar dan memberi penilaian } \\
\text { kompetensi }\end{array}$ & 3 & 3 & 4 \\
\hline $\begin{array}{l}\text { Melakukan evaluasi pembelajaran } \\
\text { Rata-rata }\end{array}$ & 3 & 3 & 4 \\
\hline Prosentase ketuntasan & 66 & 88 & 95 \\
\hline
\end{tabular}

Penerapan Metode Kooperative tipe make a match dalam pembelajaran tematik tugasku sehari-hari meliputi langkah-langkah: (1) Guru menyampaikan materi atau memberi tugas kepada siswa untuk mempelajari materi di rumah. (2) siswa dibagi kedalam 2 kelompok misalnya kelompok $\mathrm{A}$ dan $\mathrm{B}$. kedua kelompok diminta untuk berhadap-hadapan. (3) Guru memberikan kartu pertanyaan kepada kelompok A dan kartu jawaban kepada kelompok B. (4) Guru menyampaikan kepada siswa bahwa mereka harus mencari/mencocockan kartu yang di pegang dengan kartu kelompok lainnya. Guru juga perlu menyampaikan batasan maksimum waktu yang diberikan kepada mereka. (5)guru meminta semua kelompok A untuk mencari passangannya di kelompok B. jika mereka sudah menemukan pasangannya masing-masing, guru meminta mereka melaporkan diri kepadanya. Guru mencatat mereka pada kertas yang sudah dipersiapkan. (6) Jika waktu sudah habis, mereka harus diberitahu waktu sudah habis. Siswa yang belum menemukan pasangan diminta untuk berkumpul tersendiri. (7) guru memanggil satu pasangan untuk presentasi. Pasangan lain dan siswa yang tidak mendapatkan pasangan memperhatikan dan memberikan tanggapan apakah pasangan itu cocok atau tidak. (8) terakhir guru memberikan informasi tentang kebenaran dan kecocokan pertanyaan dan jawaban dari pasangan yang memberikan presentasi. (9) guru memanggil pasangan berikutnya, begitu seterusnya sampai seluruh pasangan melakukan presentasi. 
Langkah-langkah metode kooperative tipe make a match dilaksanakan dalam penelitian ini sejalan dengan penelitian yang dilakukan oleh Huda (2011) dalam Ardiana Maulidah yang melakukan penelitian dengan topik Peningkatan Hasil Belajar Tematik Subtema Tugasku Sehari-hari di rumah Menggunakan Model Pembelajaran Kooperative Tipe Make a Match pada siswa kelas II B MI Unggulan Assa'adah Surabaya.

\section{Hasil Belajar Tematik Tugasku Sehari-hari di Rumah}

Hasil penelitian menunjukkan peningkatan hasil belajar Tematik Tugasku sehari-hari di rumah Terlilhat pada tabel berikut.

Tabel 2. Peningkatan Hasil Belajar

\begin{tabular}{c|c|c|c|c|c|c}
\hline \multirow{2}{*}{ Nilai } & \multicolumn{2}{|c|}{ Siklus I } & \multicolumn{2}{c|}{ Siklus II } & \multicolumn{2}{c}{ Siklus III } \\
\cline { 2 - 7 } & $\mathbf{f}$ & $\%$ & $\mathbf{f}$ & $\%$ & $\mathbf{f}$ & $\%$ \\
\hline $\mathbf{1 0 0}$ & 5 & 17.24 & 6 & 20.7 & 16 & 55.17 \\
\hline $\mathbf{9 0}$ & 6 & 20.7 & 9 & 31.03 & 6 & 20.7 \\
\hline $\mathbf{8 0}$ & 5 & 17.24 & 7 & 24,13 & 4 & 13.8 \\
\hline $\mathbf{7 0}$ & 4 & 13.8 & 4 & 13.8 & 2 & 6.9 \\
\hline $\mathbf{6 0}$ & 4 & 13.8 & 2 & 6.9 & - & - \\
\hline $\mathbf{5 0}$ & 2 & 6.9 & 1 & 3.4 & 1 & 3.4 \\
\hline 40 & 3 & 10.34 & - & - & - & - \\
\hline $\begin{array}{c}\text { Jumlah } \\
\text { Rata- }\end{array}$ & 29 & 100 & 29 & 100 & 29 & 100 \\
\hline $\begin{array}{c}\text { Tuta } \\
\text { Tuntas }\end{array}$ & 20 & 66 & 26 & 93 & 28 & 97 \\
\hline
\end{tabular}

Peningkatan hasil belajar Tematik tugasku sehari-hari di rumah menggunakan metode kooperative tipe make a match pada peserta didik diukur dengan menggunakan teknik tes hasil belajar dengan instrument lembar soal evaluasi. Teknik pengumpulan data hasil belajar peserta didik diterapkan disetiap pertemuan setelah dilakukan proses pembelajaran. Aspek yang diukur yaitu aspek kognitif atau pengetahuan yang terdiri dari mengingat (C1), memahami (C2), menemukan (C4), dan menganalisis (C4) yang diukur berdasarkan hasil evaluasi setelah mengikuti pembelajaran dengan penggunaan metode kooperative tipe make a match.

Penggunaan metode kooperative tipe make a match dapat meningkatkan hasil belajar peserta didik di kelas II SDN Karangkandri 04 Kesugihan Cilacap secara signifikan. Pada hasil Penilaian sebelumnya terdapat 12 dari 29 peserta didik yang belum mencapai KKM dengan persentase ketuntasan hasil belajar hanya 53\%. Setelah dilakukan tindakan, persentase ketuntasan hasil belajar pada siklus I meningkat menjadi $66 \%$ dan pada pertemuan kedua menjadi $93 \%$. dan pada siklus III meningkat menjadi 97 $\%$. Berdasarkan hasil di atas, rata- rata ketuntasan hasil belajar pada siklus I sebesar $60 \%$ dan siklus II sebesar $93 \%$. dan siklus III sebesar $97 \%$.

Berdasarkan analisis hasil belajar peserta didik setelah pelaksanaan tindakan, dapat diambil kesimpulan bahwa penggunaan metode Kooperative Tipe make a match dapat meningkatkan hasil belajar Tematik Tugasku Sehari-hari di Rumah menggunakan media benda konkret. Hal ini sesuai dengan hasil penelitian yang dilakukan oleh Ardiana 
Maulidah yang membuktikan bahwa metode kooperative Tipe make a match dapat meningkatkan hasil belajar tematik Tugasku sehari-hari di rumah di kelas II SDN Karangkandri 04 Kesugihan Cilacap secara signifikan. Hasil penelitian ini juga memperkuat pendapat Huda (2011) Bahwa penggunaan metode kooperative tipe make a match berpengaruh baik pada proses pembelajaran dan hasil belajar Tematik Tugasku sehari-hari di rumah meningkat secara signifikan.

\section{SIMPULAN}

Berdasarkan hasil penelitian dan uraian pembahasan maka dapat diambil simpulan sebagai berikut. Penggunaan metode Kooperative tipe make a match untuk meningkatkan hasil belajar Tematik tugasku sehari-hari di rumah di kelas II SD Negeri Karangkandri 04 Kesugihan Cilacap Tahun Pelajaran 2020/2021 dilaksanakan dengan langkah-langkah: (1) Guru menyampaikan materi atau memberi tugas kepada siswa untuk mempelajari materi di rumah. (2) siswa dibagi kedalam 2 kelompok misalnya kelompok A dan B. kedua kelompok diminta untuk berhadap-hadapan. (3) Guru memberikan kartu pertanyaan kepada kelompok A dan kartu jawaban kepada kelompok B. (4) Guru menyampaikan kepada siswa bahwa mereka harus mencari/mencocockan kartu yang di pegang dengan kartu kelompok lainnya. Guru juga perlu menyampaikan batasan maksimum waktu yang diberikan kepada mereka. (5)guru meminta semua kelompok A untuk mencari passangannya di kelompok B. jika mereka sudah menemukan pasangannya masing-masing, guru meminta mereka melaporkan diri kepadanya. Guru mencatat mereka pada kertas yang sudah dipersiapkan. (6) Jika waktu sudah habis, mereka harus diberitahu waktu sudah habis. Siswa yang belum menemukan pasangan diminta untuk berkumpul tersendiri. (7) guru memanggil satu pasangan untuk presentasi. Pasangan lain dan siswa yang tidak mendapatkan pasangan memperhatikan dan memberikan tanggapan apakah pasangan itu cocok atau tidak. (8) terakhir guru memberikan informasi tentang kebenaran dan kecocokan pertanyaan dan jawaban dari pasangan yang memberikan presentasi. (9) guru memanggil pasangan berikutnya, begitu seterusnya sampai seluruh pasangan melakukan presentasi. Penggunaan metode Kooperative tipe make a match dapat meningkatkan hasil belajar Tematik Tugasku Sehari-hari Di Rumah di kelas II SD Negeri Karangkandri 04 Kesugihan Cilacap Tahun Pelajaran 2020/2021 yang dibuktikan dengan rata-rata ketuntasan hasil belajar peserta didik pada siklus I sebesar 60 $\%$ meningkat pada siklus II sebesar $93 \%$ dan meningkat lagi pada siklus III sebesar $97 \%$. 
SHEs: Conference Series 3 (3) (2020) $303-308$

\section{DAFTAR PUSTAKA}

Anurrahman. 2012. Belajar dan Pembelajaran. (Bandung: Alfabeta).

Hastuti, D. N. (2018). Penerapan Metode Pembelajaran Tutor Sebaya untuk Meningkatkan Keaktifan dan Hasil Belajar Siswa Pada Mata Pelajaran Desain Grafis Kelas $X$ Multimedia 1 di SMKN 1 Godean. Skripsi pada Universitas Negeri Yogyakarta. Yogyakarta: UNY.

Mujoyana, M. (2015). Penerapan model pembelajaran tutor sebaya berbantuan Power Point untuk meningkatkan hasil belajar materi himpunan kelas VII MTs Baitussalam Semarang (Doctoral dissertation, UIN Walisongo).

Sanjaya, W. (2009) Penelitian Tindakan Kelas. Jakarta: Kencana. Setiana, E. ( 2019). Informatika untuk SMP/MTs Kelas VII. Bandung: Grafindo.

Siregar, H. I. (2016). Pengelolaan Metode Tutor Sebaya dalam Meningkatkan Motivasi Belajar Siswa pada Pembelajaran Microsoft Excel di Kelas VIII-D Smp Negeri 1 Batangkuis. Jurnal Handayani PGSD FIP UNIMED, 6(1).

Munadi, Yudi.2008. Media Pembelajaran. (Jakarta: Gaung Persada)

Rusman. 2015. Pembelajaran Tematik Terpadu. (Depok: PT Raja Grafindo Persada).

Trianto. 2011. Desain Pengembangan Pembelajaran TEMATIK, (Jakarta: 